\title{
pH and organic matter impact on the indices of soil metal load assessment under wastewater and biosolid reuse
}

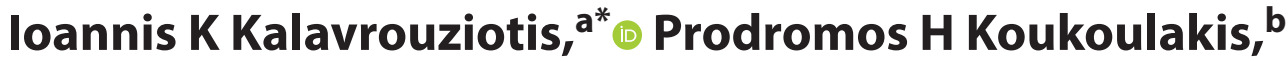 \\ Dimitrios Papaioannou a and Aradhana Mehrac
}

\begin{abstract}
BACKGROUND: Experimental data were used to study the impact of $\mathrm{pH}$ and organic matter on soil pollution indices, with the view to express them as a function of the above two variables.

RESULTS: Data were from an experiment performed in a greenhouse using 12 wastewater and sludge treatment combinations in four replications, using Lactuca sative var Longifolia as a test plant. The experimental data were analyzed by means of linear multiple regression analysis, and the equations found were considered as revised forms for the calculation of pollution indices, which could be used as a tool for the assessment of the level of soil pollution by heavy metals.

CONCLUSION: Tentative critical levels of the pollution indices were established on the basis of the reference revised Index PLIn. However, additional work is necessary, such as calibration of the revised indices on the basis of percentage crop yield loss, towards a more accurate assessment of the heavy metal soil pollution levels.

() 2018 Society of Chemical Industry
\end{abstract}

Keywords: heavy metals; pollution control; wastewater; statistical design

\section{INTRODUCTION}

The industrial and technological progress which has taken place during the last 50 years, has undoubtedly contributed to the economic advancement of modern societies as well as to their well-being. Yet, at the same time it has also created a multitude of problems related to human health risk and their quality of life. The byproducts of anthropogenic activities on a global level have contributed large quantities of toxic heavy metals, which have accumulated in soils, in surface and underground waters, and in the atmosphere ${ }^{1}$ leading to toxic effects on humans, plants and animals.

The sources of heavy metals in soils are natural and anthropogenic. According to Kabata Pendias, ${ }^{2}$ the natural sources include elements inherited directly from the lithosphere (lithogenic elements). Also there are the pedogenic elements, which are of lithospheric origin, but their concentration and distribution in soil layers and in soil particles are changed due to pedogenic processes. The anthropogenic elements are those which are deposited into the soils as a direct or indirect result of human activities. The natural sources include rock weathering, mineral breakdown, plant remains (debris), irrigation water, atmospheric deposits, seawater, while the anthropogenic sources include wastewaters, biosolids, metallurgical operations, smelters, mine tailings, fertilizers, agricultural chemicals, pesticides. ${ }^{3}$

The heavy metals originating from the above sources, accumulate in the soil over time, and as a result polluted soils are formed. This accumulation has a very strong impact on the environment. It does not only affect human beings, animals and plants, but also soil organisms, ${ }^{4}$ affecting especially their activities, as well various soil processes dependent on the soil microorganisms, such as breakdown of organic matter, nitrification, denitrification, nitrogen fixation of legumes, mineralization of organic matter and the biotic processes. ${ }^{5}$ Due to the extensive distribution of heavy metals in the terrestrial environment, ${ }^{1}$ and consequently due to soil pollution covering so many sites globally, ${ }^{3}$ this problem has become an important issue, as it is directly related to human health risk and to environmental quality.

Regarding the soil, toxic metals have accumulated and polluted many areas in the world. In a survey conducted by various organizations cited by He et al., ${ }^{6}$ universally there are $10^{7}$ sites polluted by $>50 \%$ with heavy metals, being distributed as follows: USA $10^{5}$ sites polluted by $>70 \%$, European Union by $37 \%$, Australia by $>60 \%$, while China has an area equal to $10^{6} \mathrm{~km}^{2}$ polluted by $>80 \%$ with heavy metals. In an extensive survey conducted recently in the European Union by the LUCAS top soil survey it

\footnotetext{
Correspondence to: IK Kalavrouziotis, School of Science and Technology, Hellenic Open University, Aristotelous 18, 26335 Patras, Greece.

E-mail:ikalabro@eap.gr

a School of Science and Technology, Hellenic Open University, Patras, Greece

b Hellenic Agricultural Organization 'Demetra' Soil Science Institute, Thermi, Greece

c Research and Enterprise Training Institute, University of Greenwich, London, UK
} 
has been reported that $6.24 \%$ of the agricultural land corresponding to $1.37 \times 10^{5} \mathrm{~km}^{2}$ was found to be polluted to various degrees with $\mathrm{As}, \mathrm{Cd}, \mathrm{Cr}, \mathrm{Hg}$, and $\mathrm{Pb}$, and this area needs local remediation action. ${ }^{7}$ In England and Wales an area of about $4 \times 10^{3} \mathrm{~km}^{2}$ has been reported to be contaminated with heavy metals. ${ }^{8}$ In Greece, anthropogenic agents impact has been reported by Kelepertzis ${ }^{9}$ in relation to accumulation of $\mathrm{Cu}, \mathrm{Zn}, \mathrm{Cd}$ and $\mathrm{Pb}$ in the Argolida Plain. Similar anthropogenic impact of heavy metals has been reported by Nicolson et al. ${ }^{10}$ and Luo et al. ${ }^{11}$ for the agricultural soils of China, due to anthropogenic pollution.

It has been stated, that the soil heavy metal content is increasing globally and in certain cases the pollution may become severe due mainly to anthropogenic impact. ${ }^{11}$ On the other hand, extensive integration of treated wastewater in the planning of crop irrigation has contributed to the distribution of heavy metals, along with the organic matter, to soil. ${ }^{12}$

The soil, being in close contact with the heavy metal sources, supplies the plant root system with these metals, and via plant uptake depending on the transfer factors (TF) ${ }^{12}$ the metals enter into the food chain. The latter takes place in the context of the food production capacity of soils.

Efforts have been made to clarify the effect of two soil factors, i.e. $\mathrm{pH}$ and organic matter (OM) on the behavior of the metals, which at high concentrations may become extremely toxic, affecting adversely, the biotic system and its parameters. Their harmful effects are characterized by creating serious health problems. ${ }^{13,14}$ These problems become more acute and serious due to the metals being extensively distributed, covering both biotic and abiotic environments. Furthermore, soil pollution with metals becomes more problematic due to the fact that the metals are widely distributed, they present strong latency, they are non-degradable and remediated with difficulty, and the pollution caused by them is very complex. ${ }^{15,16}$ The mobility and plant availability of heavy metals is strongly related to their toxicity. It is controlled by various factors and mechanisms such as adsorption, desorption, which play a very important role. ${ }^{17}$ Also, fixation is another significant factor affecting the mobility and availability of heavy metals in the soil. However, the factors which play a very important role are the $\mathrm{pH}$, organic matter, and the oxidation reduction potential. ${ }^{17}$ Bartlett et al. ${ }^{18}$ pointed out that $\mathrm{pH}$ is the principal factor governing the concentration of plant available metals. Also calcium carbonate seems to have a decisive role in the mobility of heavy metals. ${ }^{19,2}$ It has been noted that the soil organic matter is statistically significantly related in terms of the metal availability to plants. Soil pollution can be effectively understood if quantitative information about these factors can be assessed. Generally, the assessment of soil pollution from heavy metals may be accomplished in the following ways: ${ }^{6}$

- by sampling soil of a representative area and by soil analysis;

- by the use of commonly preferred methods for the calculation of the widely adopted Hakanson potential ecological risk;

- by calculating the Nemero comprehensive index ( $\mathrm{NCl}$ );

- by the environmental factors;

- by means of a pollution index.

Heavy metal pollution of soils is a global issue, and combating it needs systematic, effective, joint action. Critical metal levels in agricultural soils must be established for the quantitative evaluation of pollution such as those mentioned in Table 1 which are used successfully in Finland.

Standards must be established by interdisciplinary cooperation based on research work. It is also necessary that the methods used
Table 1. Threshold values, lower and higher guideline values $\left(\mathrm{mg} \mathrm{kg}^{-1}\right)^{20}$

\begin{tabular}{|lccc|} 
Metal & $\begin{array}{c}\text { Threshold } \\
\text { value }\end{array}$ & $\begin{array}{c}\text { Lower } \\
\text { guideline } \\
\text { value }\end{array}$ & $\begin{array}{c}\text { Higher } \\
\text { guideline } \\
\text { value }\end{array}$ \\
\hline Antimony (Sb) p & 2.0 & $10(\mathrm{t})$ & $50(\mathrm{e})$ \\
Arsenic (As) $p$ & 5.0 & $50(\mathrm{e})$ & $100(\mathrm{e})$ \\
Mercury (Hg) & 0.5 & $2.0(\mathrm{e})$ & $5(\mathrm{e})$ \\
Cadmium (Cd) & 1.0 & $10(\mathrm{e})$ & $20(\mathrm{e})$ \\
Cobalt (Co) p & 20.0 & $100(\mathrm{e})$ & $250(\mathrm{e})$ \\
Chromium (Cr) & 100.0 & $200(\mathrm{e})$ & $300(\mathrm{e})$ \\
Copper (Cu) & 100.0 & $150(\mathrm{e})$ & $200(\mathrm{e})$ \\
Lead (Pb) & 60.0 & $200(\mathrm{e})$ & $750(\mathrm{e})$ \\
Nickel (Ni) & 50.0 & $100(\mathrm{e})$ & $150(\mathrm{e})$ \\
Zinc (Zn) & 200.0 & $250(\mathrm{e})$ & $400(\mathrm{e})$ \\
Vanadium (V) & 100.0 & $150(\mathrm{e})$ & $250(\mathrm{e})$ \\
\hline
\end{tabular}

(e) Ecological risk or health risk; (t) if the risk of ground water contamination is higher than normal in concentrations below the lower guideline value the substances are marked with the letter ( $p)$.

to determine the extractable forms of metals are well known. Also it is important to know whether the metal values are 'total' or 'extractable'. The latter form of metals is considered the available form to plants. The guidelines must be classified into lower and higher recommendation levels indicating the need for action if exceeded. ${ }^{7}$ Higher concentration levels are defined by major land uses. The 'threshold' values are equally applied to all sites and indicate the need for further assessment. In cases where the background concentration is higher than the 'threshold' value, background values are considered as assessment of the 'threshold'. If the 'guideline value' is exceeded, then, the contaminated area presents 'ecological health risk'.

Regarding a more detailed and accurate assessment of soil pollution, various mathematical models have been suggested which can assess the level of pollution based on the heavy metal accumulation in the soil. Some of the most important ones are as follows:

a Geo-accumulation Index: this index is used to evaluate and compare current and past soil contamination using as a reference value the earth-crust metal concentration. The Igeo equation being: $\mathbf{I g e o}=\log _{\mathbf{2}}\left[\boldsymbol{C}_{\boldsymbol{n}} / \mathbf{1 . 5 B n}\right],{ }^{21}$ where $C_{n}$ is the concentration of the element in a soil sample $\left(\mathrm{mg} \mathrm{kg}^{-1}\right)$ and $B_{n}$ the geochemical element background concentration.

b The contamination factor: calculated by means of a relation described by Hakanson. ${ }^{22}$

c Enrichment factor: based on the standardization of a tested element against a reference one, i.e. of a metal characterized by low occurrence variability such as $\mathrm{Al} \mathrm{Zn}, \mathrm{Fe}$, etc, and the equation used to calculate this factor is based on an equation suggested by Buat-Menard ${ }^{23}$

d The Nemerow comprehensive index: this is considered a useful index for the evaluation of soil quality. It takes into account extreme values and also it considers weighted multifactors. It reflects the degree of soil pollution by heavy metals. Its mathematical expression is: $\mathbf{P}_{\mathrm{N}}=\left[\left((\max \mathbf{P i})^{2}+(\text { ave } \mathbf{P i})^{2}\right) / \mathbf{2}\right]^{\mathbf{1 / 2}}$; where $P_{N}$ is Nemerow's pollution index, $(\max P i)$ is the maximum single pollution index among the pollutants, (ave $\mathrm{Pi}$ ) is the average mean of single pollution indices among all the pollutants, and 
Pi the single factor pollution index which is the rate of the measured concentration of heavy metals to the standard value of the pollutants. ${ }^{24}$

e The Pollution Load Index, (PLI) ${ }^{25}$ with a critical value $<1$ suggesting lack of pollution, while $>1$ means the existence of pollution. Thus PLI index has been used as a reference index for the following indices.

$\mathrm{f}$ Elemetal pollution idex. ${ }^{12}$

g Heavy metal load. ${ }^{12}$

h Total concentration factor (TCF). ${ }^{12}$

The advantages of the methods $e, f, g$ and $h$ are that they are simple and easy to apply, and the results obtained by them reflect the contribution of each element involved in the pollution. These methods yield indices which can be used in the context of a computer program and the data needed is only the analytical results for the soil heavy metals.

Heavy metal soil pollution has been studied by a number of workers relatively satisfactorily. ${ }^{1}$ A number of publications have appeared in recent years in international literature, and specifically in relation to pollution indices ${ }^{12}$ for the evaluation of the soil heavy metal pollution level. ${ }^{26-28}$ This has been progress, as the establishment of pollution indices constituted the first step towards fighting the serious problem of pollution. Unfortunately, there has not been any further development, especially with regard to the effect of soil factors on the function of the pollution indices. Soil factors, such as $\mathrm{pH}, \mathrm{OM}$, clay content, oxidation potential and in general any other factor affecting the level of the soil heavy metals, are expected to affect the pollution indices and the assessment of polluted soil as indicated by the pollution indices. This effect is very important as the indications of pollution indices are directly affected by these factors. The aspect of the metals relation to the above factors such as to the $\mathrm{pH}$ and organic matter affecting metal pollution indices under the effect of soil pollution has not been studied so far, in spite of its importance. Quite often in the literature, reference is made to the effect of $\mathrm{pH}$ and organic matter on soil heavy metals without relating quantitatively their effect on soil pollution indices. It is considered that the information on this aspect is not sufficiently available, though it is highly significant, as the $\mathrm{pH}$ and $\mathrm{OM}$ may change dramatically the value of these pollution indices and lead to unexpected results of the pollution level assessment. The present work deals exclusively with the effect of $\mathrm{pH}$ and $\mathrm{OM}$ on the pollution indices and this is the novel contribution to science. The conclusions which will be extracted are expected to more effectively describe heavy metal soil pollution.

\section{Methodology of work}

Unpublished data of Ntazala, ${ }^{29}$ obtained from her experiment of Completely Randomized Block design with seven biosolid and five wastewater treatment combinations in four replications, i.e. (i) Control (C), (ii) $20 \% \mathrm{TMWW}+80 \% \mathrm{C}$ (iii) $40 \% \mathrm{TMWW}+60 \%$ C, (iv) $60 \%$ TMWW $+40 \%$ C, (v) $80 \%$ TMWW $+20 \%$ C, (vi) $100 \%$ TMWW +0\% C, (vii) $22.6 \mathrm{~g} /$ pot biosolid, (viii) $45.2 \mathrm{~g} /$ pot biosolid, (ix) $67.7 \mathrm{~g} /$ pot biosolid, (x) $90.3 \mathrm{~g} /$ pot biosolid, (xi) $112.9 \mathrm{~g} / \mathrm{pot}$ biosolid and (xii) 100\% TMWW $+112.9 \mathrm{~g} /$ pot biosolid. The soil analysis data under the effect of these treatments have been used as basic experimental evidence for the present work. The investigation under consideration was conducted under greenhouse conditions, the plants having been grown in pots.

The basic aim of the experiment was the study and quantitative expression of the soil pollution level by means of pollution indices. Also it was intended to determine critical levels for these indices to be used effectively in actual routine practice. It must be underlined at this point that up to now the pollution indices have been expressed only as a function of the heavy metal concentration of the soil. The present experiment additionally aimed at investigating the relationship of the pollution indices to the $\mathrm{pH}$ and $\mathrm{OM}$, with a view to accumulating more experimental information and relevant knowledge that could help to accomplish more accurate and effective assessment of the soil pollution level due to the accumulation of heavy metals in the soil via wastewater and sludge (biosolid) reuse. The reason for focusing our interest on the $\mathrm{pH}$ and OM will be explained below.

During previous research work with wastewater reuse and sludge conducted by the scientific team of School of Technology and Sciences of the Hellenic Open University, some attention had been focused on the relation of $\mathrm{pH}$ and $\mathrm{OM}$ to soil heavy metals. In most cases it was found that both of these parameters were negatively and statistically significantly related to the metals. In the mean time the scientific team was also working with pollution indices. Consequently it was thought that since the $\mathrm{pH}$ and $\mathrm{OM}$ affect strongly the heavy metal level in the soil, they must also affect pollution indices, which are dependent on the soil heavy metals. Therefore, these findings led us to study the effect of $\mathrm{pH}$ and $\mathrm{OM}$ on the pollution indices. We also found that other researchers have also studied the relation of $\mathrm{pH}$ and $\mathrm{OM}$ to soil heavy metals and that their results were in agreement with ours. ${ }^{30-33}$ So, this has been for us an additional impetus that lead us to the further study of the $\mathrm{pH}$ and $\mathrm{OM}$ relationship with pollution indices.

In addition, the results and conclusions obtained regarding the relationship of pollution indices with $\mathrm{pH}$ and organic matter were also based on the following research work: (i) relevant publications of our scientific research team, ${ }^{12}$ (ii) 3 years experimental research work by Papaioannou ${ }^{34}$ dealing with the determination of critical values of the pollution indices ${ }^{12}$ and (iii) experience gained during the last 5 years dealing with the problem of soil heavy metal pollution assessment by means of pollution indices. The unpublished data mentioned above was statistically processed by means of SPSS ver. 24 and the following results were obtained.

\section{RESULTS}

The analytical data of soil heavy metal concentrations obtained during the experimental procedure under the above mentioned treatments, is given in Table 2 . It can be seen that the highest concentrations are those of $\mathrm{Mn}$ followed by $\mathrm{Pb}, \mathrm{Cu}$ and $\mathrm{Zn}$, while the concentration of all the other metals is $<1 \mathrm{mg} \mathrm{kg}^{-1}$.

The present work was based on the following two basic procedures:

- expressing each pollution index as a function of $\mathrm{pH}$ or $\mathrm{OM}$, respectively by means of simple regression analysis; and

- expressing each pollution index as a function of both $\mathrm{pH}$ and $\mathrm{OM}$ by means of linear multiple regression analysis.

The above procedure was necessitated in order first to find out whether the relationship of the pollution indices with $\mathrm{pH}$ or with $\mathrm{OM}$ is statistically significant or not, and second, in the affirmative case, the indices could be expressed as a function of both of the above variables by means of simple linear multiple regression.

Running simple regression analysis, it was found that the pollution indices PLI, EPI, HLM and TCF were statistically significantly related to $\mathrm{pH}$ and $\mathrm{OM}$ (Figs 1 and 2, respectively). 


\begin{tabular}{|c|c|c|c|c|c|c|c|c|c|c|}
\hline & $\mathrm{pH}$ & OM (\%) & $\begin{array}{c}\mathrm{Zn} \\
\left(\mathrm{mg} \mathrm{kg}^{-1}\right)\end{array}$ & $\begin{array}{c}\mathrm{Mn} \\
\left(\mathrm{mg} \mathrm{kg}^{-1}\right)\end{array}$ & $\begin{array}{c}\mathrm{Cu} \\
\left(\mathrm{mg} \mathrm{kg}^{-1}\right)\end{array}$ & $\begin{array}{c}\mathrm{Cr} \\
\left(\mathrm{mg} \mathrm{kg}^{-1}\right)\end{array}$ & $\begin{array}{c}\mathrm{Cd} \\
\left(\mathrm{mg} \mathrm{kg}^{-1}\right)\end{array}$ & $\begin{array}{c}\text { Co } \\
\left(\mathrm{mg} \mathrm{kg}^{-1}\right)\end{array}$ & $\begin{array}{c}\mathrm{Ni} \\
\left(\mathrm{g} \mathrm{kg}^{-1}\right)\end{array}$ & $\begin{array}{c}\mathrm{Pb} \\
\left(\mathrm{mg} \mathrm{kg}^{-1}\right)\end{array}$ \\
\hline & 5.96 & 1.24 & 1.80 & 50.17 & 2.84 & 0.03 & 0.04 & 0.13 & 0.36 & 7.96 \\
\hline & 5.87 & 1.32 & 1.83 & 47.09 & 2.22 & 0.02 & 0.04 & 0.12 & 0.39 & 6.84 \\
\hline & 5.95 & 1.44 & 3.55 & 46.96 & 2.22 & 0.02 & 0.04 & 0.12 & 0.44 & 10.60 \\
\hline & 5.84 & 1.41 & 1.58 & 45.20 & 2.37 & 0.02 & 0.05 & 0.11 & 0.41 & 7.09 \\
\hline & 564 & 1.42 & 1.98 & 46.60 & 2.46 & 0.02 & 0.04 & 0.12 & 0.38 & 6.89 \\
\hline & 5.70 & 1.38 & 2.28 & 48.93 & 2.76 & 0.03 & 0.05 & 0.12 & 0.41 & 7.65 \\
\hline & 5.60 & 1.42 & 2.37 & 49.25 & 2.38 & 0.04 & 0.05 & 0.13 & 0.43 & 7.91 \\
\hline & 5.59 & 1.56 & 1.98 & 49.15 & 2.46 & 0.03 & 0.04 & 0.13 & 0.44 & 7.63 \\
\hline & 5.60 & 1.40 & 3.04 & 47.86 & 2.34 & 0.03 & 0.04 & 0.12 & 0.43 & 8.42 \\
\hline & 5.61 & 1.42 & 2.24 & 49.71 & 2.75 & 0.03 & 0.04 & 0.13 & 0.41 & 7.92 \\
\hline & 5.37 & 1.55 & 1.86 & 45.13 & 2.52 & 0.04 & 0.04 & 0.12 & 0.46 & 7.32 \\
\hline & 5.81 & 1.40 & 1.39 & 48.90 & 2.68 & 0.03 & 0.05 & 0.12 & 0.0 .38 & 7.03 \\
\hline $\begin{array}{l}\text { Standard } \\
\text { deviation }\end{array}$ & 0.176 & 0.086 & 0.610 & 1.707 & 0.212 & 0.007 & 0.003 & 0.006 & 0.031 & 1.019 \\
\hline
\end{tabular}
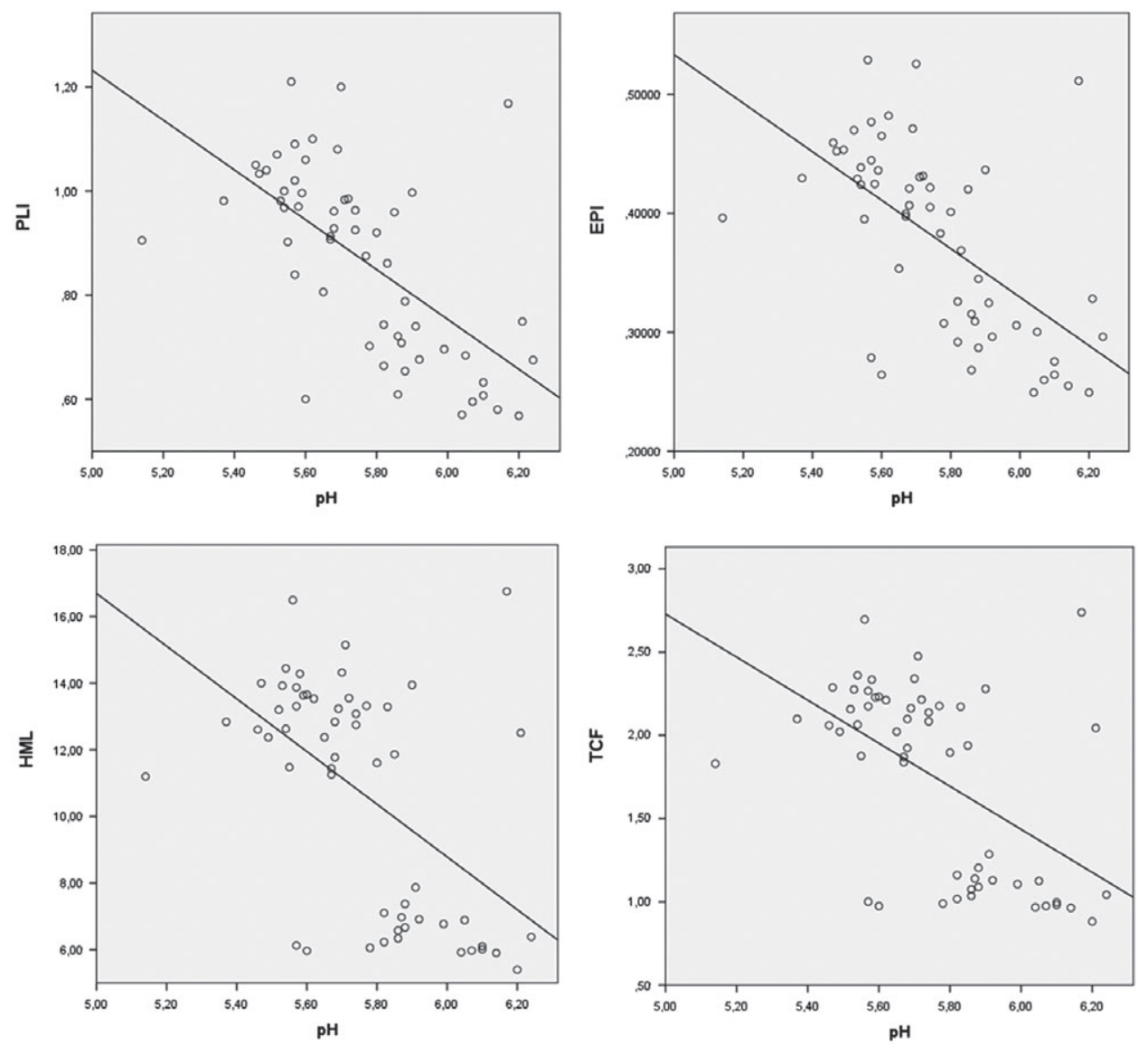

Figure 1. Regression between pollution indices and soil pH.

In Fig. 1, it is seen that all the studied indices are negatively linearly and statistically significantly related to soil $\mathrm{pH}$ $(P<0.000)$.

Similarly, in Fig. 2 it is seen that the above indices are also negatively, linearly, and significantly related to the $\mathrm{OM},(P<0.000)$.

Furthermore, careful study of the data of Table 3 which shows the regression equations of the pollution indices as a function of $\mathrm{pH}$ and OM reveals that not only the ANOVA of the regression, but also each one of its corresponding parameters is highly statistically significant $(P<0.000)$. These results led to the second step of the hypothesis: The pollution indices studied, could be expressed as a function of both $\mathrm{pH}$ and $\mathrm{OM}$ in the form of a linear multiple regression equation (Table 3 ).

Based on the above results, each pollution index was in turn expressed as a function of both $\mathrm{pH}$ and $\mathrm{OM}$ by means of linear multiple regression analysis, and the new indices which were 

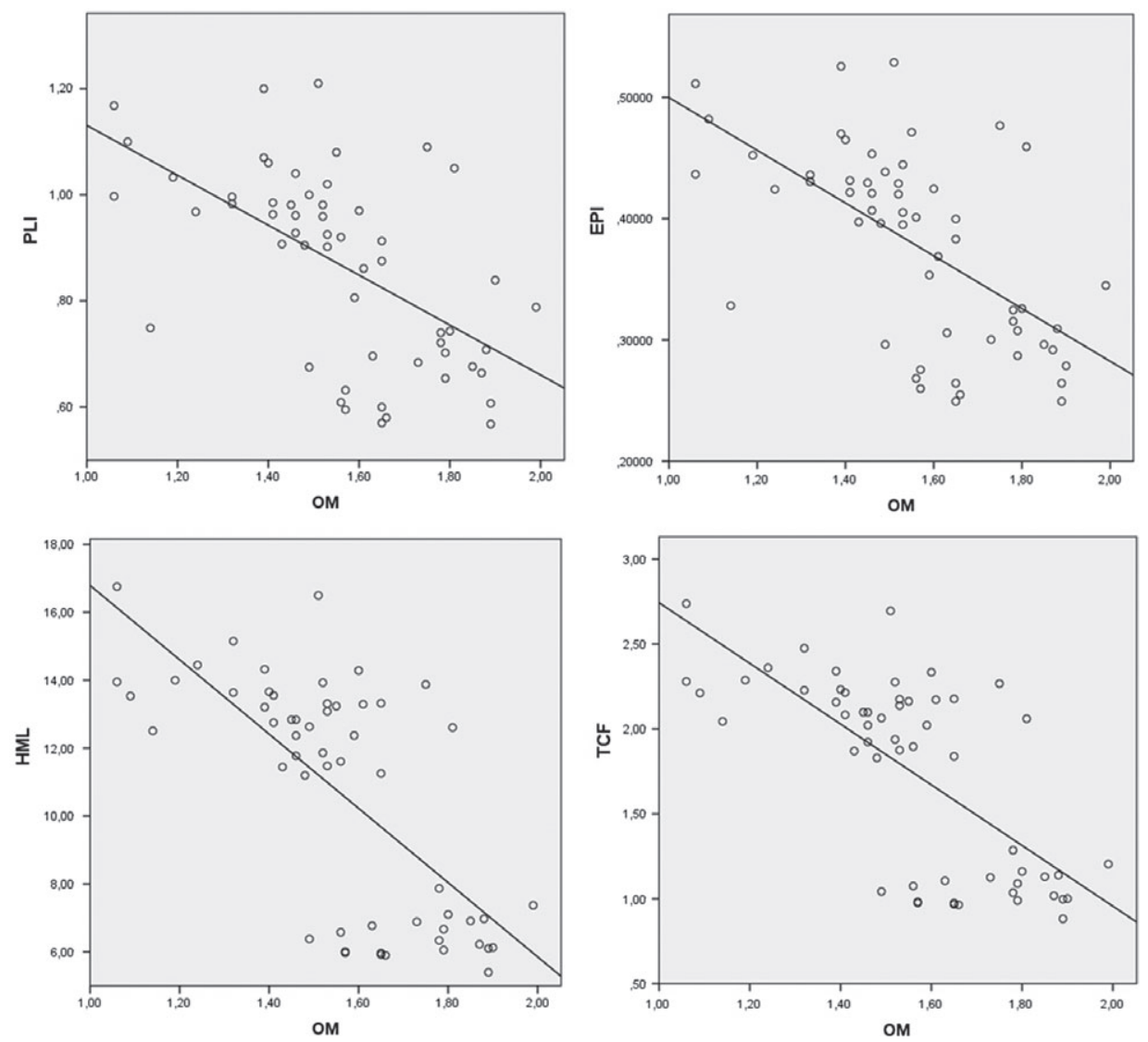

Figure 2. Relation between pollution indices and soil organic matter (OM).

\begin{tabular}{|c|c|c|c|c|c|}
\hline Equation & Relationship & $\begin{array}{l}\text { Parameter } \\
\text { (predictors) }\end{array}$ & Signif. & $\begin{array}{l}\text { Regression } \\
\text { coefficient } \mathrm{R}\end{array}$ & $\begin{array}{c}\text { ANOVA } \\
\text { signif. }\end{array}$ \\
\hline \multirow[t]{2}{*}{$\mathrm{PLI}=-0.479(\mathrm{pH})+3.626$} & \multirow[t]{2}{*}{ Linear } & $-0.479(\mathrm{pH})$ & 0.000 & \multirow[t]{2}{*}{0.622} & \multirow[t]{2}{*}{0.000} \\
\hline & & Con +3.626 & 0.000 & & \\
\hline \multirow[t]{2}{*}{$\mathrm{PLI}=-0.471(\mathrm{OM})+1.601$} & \multirow[t]{2}{*}{ Linear } & $-0.471(\mathrm{OM})$ & 0.000 & \multirow[t]{2}{*}{0.581} & \multirow[t]{2}{*}{0.000} \\
\hline & & Con +1.601 & 0.000 & & \\
\hline \multirow[t]{2}{*}{$E P I=-0.204(p H)+1.552$} & \multirow[t]{2}{*}{ Linear } & $-0.204(\mathrm{pH})$ & 0.000 & \multirow[t]{2}{*}{0.598} & \multirow[t]{2}{*}{0.000} \\
\hline & & Con +1.552 & 0.000 & & \\
\hline \multirow[t]{2}{*}{$E P I=-0.218(\mathrm{OM})+0.757$} & \multirow[t]{2}{*}{ Linear } & $-0.218(\mathrm{OM})$ & 0.000 & \multirow[t]{2}{*}{0.606} & \multirow[t]{2}{*}{0.000} \\
\hline & & Con +0.757 & 0.000 & & \\
\hline \multirow[t]{2}{*}{$\mathrm{HML}=-7.911(\mathrm{pH})+56.249$} & \multirow[t]{2}{*}{ Linear } & $-7.911(\mathrm{pH})$ & 0.000 & \multirow[t]{2}{*}{0.532} & \multirow[t]{2}{*}{0.000} \\
\hline & & Con +56.249 & 0.000 & & \\
\hline \multirow[t]{2}{*}{$\mathrm{HML}=-10.937(\mathrm{OM})+27.725$} & \multirow[t]{2}{*}{ Linear } & $-10.937(\mathrm{OM})$ & 0.000 & \multirow[t]{2}{*}{0.698} & \multirow[t]{2}{*}{0.000} \\
\hline & & Con +27.725 & 0.000 & & \\
\hline \multirow[t]{2}{*}{$\mathrm{TCF}=-1.293(\mathrm{pH})+9.191$} & \multirow[t]{2}{*}{ Linear } & $-1.293(\mathrm{pH})$ & 0.000 & \multirow[t]{2}{*}{0.532} & \multirow[t]{2}{*}{0.000} \\
\hline & & Con +9.191 & 0.000 & & \\
\hline \multirow[t]{2}{*}{$\mathrm{TCF}=-1.787(\mathrm{OM})+4.530$} & \multirow[t]{2}{*}{ Linear } & $-1.787(\mathrm{OM})$ & 0.000 & \multirow[t]{2}{*}{0.698} & \multirow[t]{2}{*}{0.000} \\
\hline & & Con +4.530 & 0.000 & & \\
\hline
\end{tabular}

found (PLIn, EPIn, HMLn, and TCFn) are the revised form of the older ones (PLI, EPI,HML, and TCF) ${ }^{12}$ (Table 4).

To further test the revised indices (PLIn, EPIn, HMLn, TCFn) they were compared with their original counterparts (PLI, EPI, HML and TCF). ${ }^{12}$ The relevant results are given in Table 5 . As shown in this table the results of the correlation were highly statistically significant $(P=0.000)$.
To further strengthen the results of the present work, a regression analysis and a paired t-test was run between the data of the revised pollution indices and the reference index PLIn, the relevant results being shown in Table 6.

Study of Table 6 reveals that both the regression analysis and the paired t-test between these pollution indices were statistically significant, a fact that showed that the condition of high significance 
Table 4. Equations of linear multiple regression analysis expressing the revised pollution indices PLIn, EPIn, HMLn and TCFn as a function of $\mathrm{pH}$ and OM of soil

\begin{tabular}{|c|c|c|c|c|c|}
\hline Multiple regression equation & Relationship & $\begin{array}{l}\text { Parameters } \\
\text { (predictors) }\end{array}$ & Signif. & $\begin{array}{l}\text { Regression } \\
\text { coefficient } R\end{array}$ & $\begin{array}{l}\text { ANOVA } \\
\text { signific. }\end{array}$ \\
\hline \multirow[t]{3}{*}{ PLIn $=-0.411(\mathrm{pH})-0.392(\mathrm{OM})+3.847$} & \multirow[t]{3}{*}{ Linear } & $-0.411(\mathrm{pH})$ & 0.000 & \multirow[t]{3}{*}{0.783} & \multirow[t]{3}{*}{0.000} \\
\hline & & $-0.392(\mathrm{OM})$ & 0.000 & & \\
\hline & & Con +3.847 & 0.000 & & \\
\hline \multirow[t]{3}{*}{$\mathrm{EPIn}=-0.172(\mathrm{pH})-0.185(\mathrm{OM})+1.657$} & \multirow[t]{3}{*}{ Linear } & $-0.172(\mathrm{pH})$ & 0.000 & \multirow[t]{3}{*}{0.999} & \multirow[t]{3}{*}{0.000} \\
\hline & & $-0.185(\mathrm{OM})$ & 0.000 & & \\
\hline & & Con +1.657 & 0.000 & & \\
\hline \multirow[t]{3}{*}{$\mathrm{HMLn}=-6.232(\mathrm{pH})-9.745(\mathrm{OM})+61.763$} & \multirow[t]{3}{*}{ Linear } & $-6.232(\mathrm{pH})$ & 0.000 & \multirow[t]{3}{*}{0.810} & \multirow[t]{3}{*}{0.000} \\
\hline & & $-9.745(\mathrm{OM})$ & 0.000 & & \\
\hline & & Con +61.763 & 0.000 & & \\
\hline \multirow[t]{3}{*}{$\mathrm{TCFn}=-1.018(\mathrm{pH})-1.592(\mathrm{OM})+10.092$} & \multirow[t]{3}{*}{ Linear } & $-1.018(\mathrm{pH})$ & 0.000 & \multirow[t]{3}{*}{0.810} & \multirow[t]{3}{*}{0.000} \\
\hline & & $-1.592(\mathrm{OM})$ & 0.000 & & \\
\hline & & Con +10.092 & 0.000 & & \\
\hline
\end{tabular}

Table 5. Relationship of the revised multiple linear regression equations PLIn, EPIn, HMNn and TCFn with their original counterparts PLI, EPI, HML and TCF

\begin{tabular}{|c|c|c|c|c|c|}
\hline Equation & Relationship & $\begin{array}{l}\text { Parameters } \\
\text { (predictors) }\end{array}$ & Signif. & $\begin{array}{l}\text { Correlation } \\
\text { coefficient R }\end{array}$ & $\begin{array}{l}\text { ANOVA } \\
\text { signific. }\end{array}$ \\
\hline \multirow[t]{2}{*}{$P L I n=0.613(P L I)+0.336$} & \multirow[t]{2}{*}{ Linear } & $0.613(\mathrm{PLI})$ & 0.000 & \multirow[t]{2}{*}{0.783} & \multirow[t]{2}{*}{0.000} \\
\hline & & Con +0.336 & 0.000 & & \\
\hline \multirow[t]{2}{*}{$E P I n=0.614(E P I)+0.146$} & \multirow[t]{2}{*}{ Linear } & $0.614(\mathrm{EPI})$ & 0.000 & \multirow[t]{2}{*}{0.782} & \multirow[t]{2}{*}{0.000} \\
\hline & & Con +0.146 & 0.000 & & \\
\hline \multirow[t]{2}{*}{$\mathrm{HMLn}=0.675(\mathrm{HML})+3.664$} & \multirow[t]{2}{*}{ Linear } & $0.675(\mathrm{HML})$ & 0.000 & \multirow[t]{2}{*}{0.810} & \multirow[t]{2}{*}{0.000} \\
\hline & & Con +3.664 & 0.000 & & \\
\hline \multirow[t]{2}{*}{$\mathrm{TCFn}=0.657(\mathrm{TCF})+0.607$} & \multirow[t]{2}{*}{ Linear } & 0.657 (TCF) & 0.000 & \multirow[t]{2}{*}{0.810} & \multirow[t]{2}{*}{0.000} \\
\hline & & Con +0.607 & 0.000 & & \\
\hline
\end{tabular}

Table 6. (a) Regression analysis between the revised multiple regression equations EPIn, HMLn and TCFn with the revised reference regression equation PLIn and (b) paired t-test between the revised indices EPIn, HMLn, TCF, and PLIn, respectively

\begin{tabular}{|c|c|c|c|c|}
\hline Regression equation & $\begin{array}{l}\text { Regression } \\
\text { coefficient } \mathrm{R}\end{array}$ & Significance & Relationship & $\begin{array}{c}\text { Degrees of } \\
\text { freedom }\end{array}$ \\
\hline \multicolumn{5}{|c|}{ I. Regression analysis } \\
\hline$E P I n=0.443 \times$ PLIn -0.027 & 0.998 & 0.000 & Linear & 55 \\
\hline HMLn $=19.604 \times P L I n-6.351$ & 0.980 & 0.000 & Linear & 55 \\
\hline $\mathrm{TCFn}=2.034 \times \mathrm{PLIn}+1.539$ & 0.981 & 0.000 & Linear & 55 \\
\hline \multicolumn{5}{|c|}{ II. Paired sample t-tests } \\
\hline PLIn vs EPIn & $t=48.703$ & 0.000 & - & 55 \\
\hline PLIn vs HMLn & $t=27.397$ & 0.000 & - & 55 \\
\hline PLIn vs TCFn & $t=116.822$ & 0.000 & - & 55 \\
\hline
\end{tabular}

set at the beginning of this work was fully justified, and that the original hypothesis was correct, i.e. the revised pollution indices expressed as a function of $\mathrm{pH}$ and $\mathrm{OM}$ and based on the statistical significance seem to be equally effective in assessing the soil pollution level with heavy metals and consequently they could be used in the assessment of the level of soil pollution. Therefore, there no differences regarding their effectiveness and the results so obtained by these indices are not expected to differ significantly.

\section{DISCUSSION}

The role of $\mathrm{pH}$ in the behavior of heavy metals in soil has been mentioned in the previous section. Furthermore the experimental results of this work have shown that the factors $\mathrm{pH}$ and OM play an important role in determining the values of the pollution indices. These factors seem to affect significantly the pollution indices, a fact that reflects the extent of accuracy of these indices. According to the experimental results obtained, $\mathrm{pH}$ and $\mathrm{OM}$ at high levels can even give negative values of pollution indices, meaning that 
the soil is not polluted. Consequently, it was concluded that the $\mathrm{pH}$ has a dominant role not only in the mobility and availability of heavy metals in the soil, but also on the level of soil pollution as it affects the final value of the pollution indices. A similar conclusion was drawn regarding the organic matter with its relation to the soil heavy metals, playing an important role in controlling their levels in soil. ${ }^{35-37}$ Many other workers have shown that both $\mathrm{pH}$ and OM play an important role in regulating the bioavailable level of heavy metals in soil. ${ }^{30-33}$ Thus, the present experimental data, showed that the pollution indices are statistically significantly associated with the $\mathrm{pH}$ and $\mathrm{OM}$ and this finding has led our team to work with more detailed interest and with scrutiny in relation to understanding the role of organic matter in the more accurate assessment of the soil pollution level.

According to Stevenson and Cole, ${ }^{38}$ organic matter forms complexes with metals and as a result affects significantly their level in the soil. The formation of complexes is due to the fact that the metals are polyvalent and consequently, they act as linkages between humic substances and clay minerals. Therefore, they can alter the aggregate structure and the soil properties. It has thus been supported by the above workers that the ameliorating effects on toxic metals are due to the role of organic matter which can act as a buffer. The fact that the organic matter plays an important role in controlling the soil metals, has also led to the use of organic microbial biomass as a means of assessing the level of soil contamination with heavy metals, ${ }^{39}$ which is being considered as an indicator of the level of soil contamination. ${ }^{40}$

Low metal contamination of soil favors significantly the microbial biomass, while acute contamination may have opposite results. Obviously, the low metal levels contribute to the increase of the microbial biomass due to their less toxic effect and to the fact that some metals at low concentration may affect favorably the growth of microorganisms.

The relation of heavy metals to organic matter has been examined carefully with the view to being used as the determining factor of the soil metal assessment. According to the experimental evidence obtained, organic matter is very closely related to the availability and mobility of the soil heavy metals. This relationship is generally negative, but occasionally it may also be positive, as well. It depends on the degree of dissociation of the organic complex. ${ }^{38}$ Due to the binding effect of organic matter on the heavy metals, the latter has been used successfully as a means of amelioration of heavy metal polluted soils. ${ }^{41}$

\section{The relation of $\mathrm{pH}$ and organic matter to pollution indices}

The indices are considered a useful tool for the assessment of soil pollution with heavy metals. So far, these indices have been expressed only as a function of the soil heavy metal concentration. ${ }^{12,42,43}$

The statistical processing of the unpublished data during the present work showed that there is a strong negative relation between soil heavy metals, $\mathrm{pH}$ and organic matter. The idea of the above statistical processing aimed at statistically testing these relationships, and in an affirmative case the intention was to express it as a function of $\mathrm{OM}^{42}$ and $\mathrm{pH}$. The experimental evidence, based on unpublished data for the relationship between metal availability and $\mathrm{pH}$ and $\mathrm{OM}$, showed that these two variables are dominant factors controlling the availability of heavy metals in the soil. ${ }^{17,44}$ Therefore, these relationships between the pollution indices and the $\mathrm{OM}$ and $\mathrm{pH}$ have been used as a basis for the expression of pollution indices PLI, EPI, HML, and TCF as a function of these variables. It must be mentioned that both the values of the $\mathrm{pH}$ and OM as shown in Table 2 are the result of the effect of the applied treatments as reported in this table. Therefore they are not due to original $\mathrm{pH}$ or OM treatment applied by the researcher. That is why the values of $\mathrm{pH}$ and $\mathrm{OM}$ are relatively low but strong enough to give statistically significant results and to contribute to the establishment of the mathematical models by means of multiple linear regression analysis. The relevant relationships attained are reported in Table 4. The new pollution indices, so obtained, are considered 'revised ones'. And they could tentatively be used in actual practice as a helpful tool in assessing the level of heavy metals soil pollution. They have been tested as to their statistical significance of their regression, as well as for their separate parameters (predictors) of each equation (Table 4). To further strengthen their significance, these indices were correlated with the data given by the calculation of PLI, which originally was used as a reference index. ${ }^{12}$ Also, a regression analysis was run in order to find the relationship of these three revised indices EPIn, HMLn, and TCFn with their corresponding original counterpart indices. It was found that they were highly significantly related with the latter reference index (Table 5). Finally, the regression analysis was run between each revised index, i.e. EPIn, HMLn, TCFn with the revised reference index PLIn, respectively, and a paired t-test of the above three indices with the reference index PLIn, was conducted, which gave similarly statistically highly significant results $(P=0.000)$ reported in Table 6 suggesting the strong relationship of the revised indices with the reference index PLIn.

The above results showed that the revised indices could probably be used as a tool for assessing the soil pollution level.

At this point it is necessary to explain why the above indices could give, with increase of $\mathrm{pH}$ and $\mathrm{OM}$, negative values. It is necessary to understand why this negativity could happen. As is shown in Table 4 where the equations of the new revised indices are reported, all the parameters, with the exception of the constants, are negative, while the constants are positive. This means that at higher values of $\mathrm{pH}$ and $\mathrm{OM}$ high negative products are attained and their algebraic sum with the constant can exceed the latter, and consequently the value of the corresponding index will be negative. The question which arises here is: what does a negative index value mean? The answer is that given the negative effect of both $\mathrm{pH}$ and $\mathrm{OM}$ on the values of indices, it is logical to expect that the toxic effects of heavy metals in the soil is being inactivated by either precipitation, organic complex formation, adsorption, fixation by the clay minerals. Consequently, such a negative index reflects lack of pollution as the toxic effects of heavy metals are supposedly inactivated by the high $\mathrm{pH}$ and OM. In fact, this explanation is in line with results of the relevant research work which has been conducted universally during the last 20-30 years.

Part of this research has already been mentioned in the introduction to this paper. However, to further support the negative relation of $\mathrm{pH}$ and $\mathrm{OM}$ with the soil heavy metals it is considered necessary to give additional experimental evidence on this negative relation to completely document the explanation given above about the negative values of the indices and their meaning in relation to soil pollution level. Thus, according to the information of the scientific literature the relation of $\mathrm{pH}$ and of $\mathrm{OM}$ is negative and highly statistically significant. ${ }^{45}$ The soil has great capacity to bind heavy metals on hydroxides, oxides, carbonates and phosphate precipitations under changing $\mathrm{pH}$, and this binding increases with the increase of $\mathrm{pH}$ under alkaline conditions. Some oxides, such as those of Fe and Mn play an important role in the adsorption of metals which are adsorbed more strongly on the surfaces of these metals. For example, $\mathrm{Pb}$ is adsorbed 40 times more strongly on $\mathrm{Mn}$ 
oxides than on Fe-oxides. ${ }^{46}$ On the other hand, under acidic conditions, the organic matter constitutes the main absorbing medium due to its high chemical affinity with the ions of the metals such as $\mathrm{Ni}^{47}$ Some metals, under the effect of neutral or basic $\mathrm{pH}$, can form on the surface of the soil minerals layered double hydroxides $(\mathrm{LDH}){ }^{48}$ The formation of these $\mathrm{LDH}$, according to Peltier et al.. ${ }^{49}$ constitutes the pathway to $\mathrm{Ni}$ fixation. Also, $\mathrm{CaCO}_{3}$ plays an important role in the adsorption of $\mathrm{Ni}$ due to the formation of a complex compound with the calcium carbonate..$^{50} \mathrm{pH}$ seems to be the main controlling factor of $\mathrm{Ni}$ adsorption in oxic soils. Thus, it has been reported that low $\mathrm{pH}$ increases the availability of $\mathrm{Ni}$, while the increase of $\mathrm{pH}$ decreases the level of the DTPA extractable $\mathrm{Ni}^{29}$

Another factor related to the mobility and availability of metals, and hence to soil pollution, is the extent of adsorption. $\mathrm{pH}$ has an important role in the solubility and availability of metals. For example the $\mathrm{Cr}$ adsorption on oxides of $\mathrm{Al}$ and $\mathrm{Fe}$ is favored by the high $\mathrm{pH} .{ }^{18}$ Thus the chromic ions remain immobilized in the soil at a $\mathrm{pH} 7.2$ due to precipitation and adsorption. The adsorption of $\mathrm{Cr}$ is affected by the high $\mathrm{pH} .{ }^{51}$ On the other hand, in an acidic environment $\mathrm{Cr}$ is characterized by considerable mobility. ${ }^{52}$ The adsorption of $\mathrm{Cr}$ increases with the rise of $\mathrm{pH}$ and with the increase of OM, with a negative effect on its availability and pollution level of soil.

Furthermore, the bioavailability of metals seems to be strongly affected by the $\mathrm{pH}$, such as that of $\mathrm{Co}$, which is also affected by the OM. ${ }^{44}$ Regarding the solubility of metals, $\mathrm{pH}$ also plays an important role as in the case of $\mathrm{Zn}$, whose solubility decreases by 100 times for each increase of $\mathrm{pH}$ by one $\mathrm{pH}$-scale unit. ${ }^{53}$ Decrease of $\mathrm{pH}$ immobilizes the solubility of $\mathrm{Zn}$ and consequently increases its availability to plants, and hence intensifies its participation in soil pollution. Also, increase of $\mathrm{pH}$ with liming decreases considerably the bioavailability of $\mathrm{Zn}$ and its effect on soil pollution. In well aerated soils and at $\mathrm{pH}<5.5$, the availability of $\mathrm{Mn}$ is highly favored. Among the factors which affect the availability of metals, $\mathrm{pH}$ seems to have a dominant position, followed by organic matter. Consequently the uptake of some metals such as $\mathrm{Mn}$ is strongly controlled by the organic matter. ${ }^{54} \mathrm{pH}$ is also related to the solubility of As in water. Its maximum bioavailability is at a $\mathrm{pH}<5.5$ at which its maximum plant uptake occurs. Also, the binding capacity of soil for heavy metals increases with the increase of $\mathrm{pH}$ with the exception of $\mathrm{As}, \mathrm{Mo}, \mathrm{Se}, \mathrm{V}$, and $\mathrm{Cr}$. With increase of $\mathrm{pH}$, maximum mobility of Se occurs, while with decrease of the clay level in soil the mobility of Se increases. ${ }^{55,56}$ As happens with many other metals, the adsorption of Se in soil is favored by low or by very high $\mathrm{pH}$ and decreases between $\mathrm{pH} 2.5$ and 10.0. ${ }^{57}$

In addition, $\mathrm{pH}$ may play an important role in the interactions of As with the nanoparticles of soil because $\mathrm{pH}$ can affect the electrical load of the sorbent. ${ }^{58}$ Maximum adsorption of As(III) takes place at $\mathrm{pH}$ 9, while for $\mathrm{As}(\mathrm{V})$ it is at $\mathrm{pH}$ varying between 4 and 5 . Also $\mathrm{pH}$ is a factor which determines the distribution of $\mathrm{Cu}$ in soils, whose mobility increases with the decrease of $\mathrm{pH}$ and decreases with the increase of $\mathrm{pH}^{58}$

Based on the above extensive scientific experimental evidence, it is easily understood why the pollution indices attain negative values under the effect of increasing levels of $\mathrm{pH}$ and $\mathrm{OM}$. And as this effect is highly statistically significant, it is logical to infer that the soil pollution decreases in the presence of high $\mathrm{pH}$ and organic matter, and therefore it is justified to conclude that a soil with negative pollution index is not polluted with heavy metals.
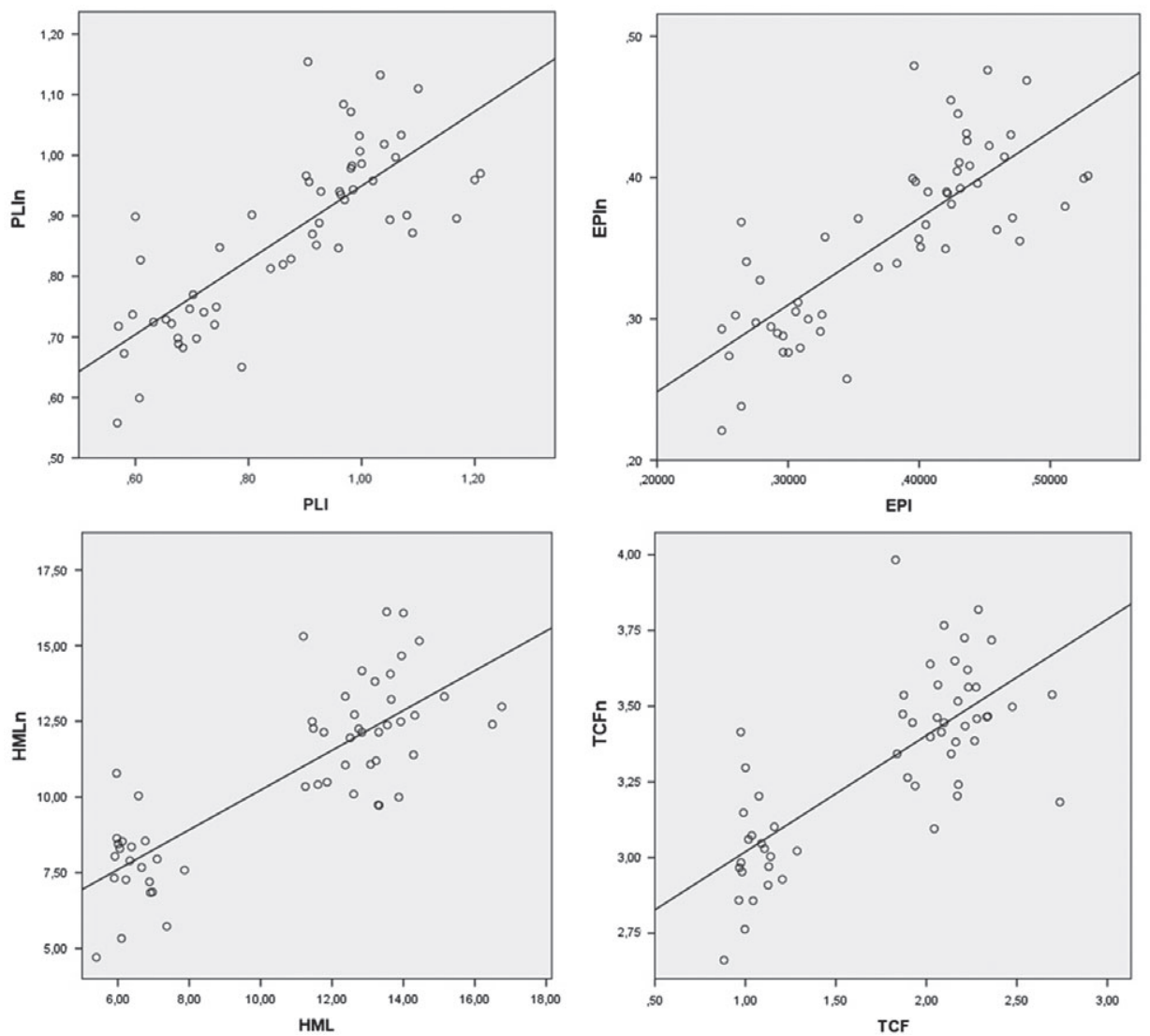

Figure 3. Relationship between the revised pollution indices and their original counterparts. 


\section{Critical levels of the revised pollution indices}

The critical levels of the revised indices, denoting lack of soil pollution, have been calculated on the basis of the regression equation associating each revised index (EPIn, HMLn and TCFn) as dependent variables with the reference index (PLIn), respectively, as independent variable, whose critical level is $\leq 1$ denoting lack of pollution. Using the regression equations of Table 5, representing the relationships between the revised indices and their original counterparts depicted in Fig. 3, the critical levels for each revised index below which there is lack of soil pollution, were calculated as follows: PLIn $=0-1$, EPIn $=0-0.394, \mathrm{HML} n=0-12.73$, and TCF $=0-2.471$.

It must be underlined here that these critical values are tentative for the time being, as they have to be calibrated on the basis of percentage loss of plant yields so as to be more accurate in the assessment of soil pollution level.

\section{CONCLUSIONS}

Based on the above presentation, the following were shown:

(a) According to the experimental data obtained from the present investigation, it was shown that there is a statistically significant relationship between the pollution indices and the soil factors $\mathrm{pH}$ and organic matter (OM). Consequently, the pollution indices: studied, i.e. Pollution Load Index (PLI), Elemental Pollution Index (EPI), Heavy Metal Load (HML), and Total Concentration Factor (TCF), which were previously expressed as a function only of soil heavy metal concentration, have been revised and expressed as a function of $\mathrm{pH}$ and $\mathrm{OM}$ by means of linear multiple regression analysis. This result was based on the fact that both the $\mathrm{pH}$ and $\mathrm{OM}$ were statistically and significantly related to the level of immobilization and to adsorption of the soil heavy metals, a fact that is directly associated with the soil pollution level and hence with the pollution indices.

(b) This above revision of the studied pollution indices, was necessitated by the urgent need to attain more realistic and actual assessment of the soil pollution level under the effect of wastewater and sludge reuse and of course under the influence of $\mathrm{pH}$ and $\mathrm{OM}$, which indeed have a statistically significant impact on the soil heavy metals, provided that these revised indices will also be calibrated on the basis of the percentage yield loss of crops.

(c) However, more research work is necessary which will include the study of additional factors that affect the soil metals, such as clay content of soil, and oxidation reduction potential, towards accomplishing more realistic indices that will accurately assess the level of soil pollution.

The above soil factors have a very strong effect on the final value of the pollution indices, a fact that so far has been ignored, and consequently the assessment of heavy metal soil pollution level which is based on the pollution indices may be considered in many cases questionable, since the latter are determined as a simple function of only heavy metals. According to the results of this work, the inclusion in the expression of the indices as a function of $\mathrm{pH}$ and $\mathrm{OM}$, and possibly of other soil factors, may cause dramatic quantitative changes of the pollution indices values.

\section{REFERENCES}

1 Adriano DC, Trace Elements in Terrestrial Environments, 2nd edn. Springer, New York (2001).
2 Kabata-Pendias A, Trace Elements in Soil and Plants, 4th edn. CRC Press, Taylor and Francis Group Boca Raton FL USA (2011).

3 Kalavrouziotis IK, Koukoulakis PH and Kostakioti E, Assessment of metal transfer factor under irrigation with treated municipal wastewater. Agric Water Manag 103:114-119 (2011).

4 Shi W, Bischoff M, Turco R and Konopka A, Long-term effects of chromium and lead upon the activity of soil microbial communities. App/ Soil Ecol 21:169-177 (2002).

5 Giller KE, Witter E and McGrath SP, Toxicity of heavy metals to microorganisms and microbial processes in agricultural soils: a review. Soil Biol Biochem 30:1389-1414 (1998).

6 He Z, Shentu J, Yang X, Baligar VC, Zhang T and Stofella PJ, Heavy metal contamination of soils: sources, indicators and assessments. J Environ Indic 9:17-18 (2015).

7 Toth G, Herman I, Da Silva MR and Montanarella L, Heavy metals in agricultural soils in European Union with implications for food safety. Environ Int 88:299-309 (2016).

8 Thornton I, Geochemical aspects of heavy metal pollution and agriculture in England and Wales, in Proceedings of a Conference organized by the Agricultural development and Advisory Service, MAFF, London, pp. 105-125 1980.

9 Kelepertzis E, Accumulation of heavy metals in agricultural soils of mediterranean: insights from Argolida basin, Peloponnese, Greece. Geoderma 221-222:82-90 (2014).

10 Nickolson FA, Smith SR, Alloway BJ, Carlton-Smith C and Chambers BJ, An inventory of heavy metals inputs to agricultural soils in England and Wales. Sci Total Environ 111:205-219 (2003).

11 Luo C, Yand R, Wang Y, Li J, Zhang G and Li X, Influence of agricultural practice on trace metals in soils and vegetation in the water conservation area along the East River (Dongjiang river), South China. Sci Total Environ 431:26-32 (2012).

12 Kalavrouziotis IK, Koukoulakis PH, Ntzala G and Papadopoulos AH, Proposed indices for assessing soil pollution under the application of sludge. Water Air Soil Pollut 223:5189-5196 (2012).

13 Su C, Jiang $L$ and Zhang $W$, A review of heavy metal contamination in the soil worldwide: situation, impact and remediation techniques. Environ Skep Crit 3:24-38 (2014).

14 Yang YB and Sun LB, Status and control countermeasures of heavy metal pollution in urban soil. Environ Protect Sci 35:79-81 (2009).

15 Wood JM, Biological cycles for toxic elements in the environment. Science 183:1049-1052 (1974).

16 Zhou QX, Ecology of Compound Pollution. China Environmental Science Press, Bijing, China (1995).

17 Koukoulakis PH, Kalavrouziotis IK and Kokkinos P, The Geochemical Behavior of Heavy Metals in the Environment. TZIOLAS Publishers Thessaloniki, Greece (in Greek), p. 534 (2017).

18 Bartlett RJ, Manganese redox reactions and organic interactions in soils, in Manganese in Soils and Plants, ed. by Graham RD, Hannam RJ and Uren NC. Kluwer Academic Publishers, Dordrecht, The Netherlands, pp. 59-73 (1988).

19 Antonladis V, Robinson JS and Alloway BJ, Effects of short-term pH fluctuations on cadmium, nickel, lead, and zinc availability to ryegrass in a sewage sludge-amended field. Chemosphere 71:759-764 (2008).

20 MEF, Ministry of Environment Finland. Government Decree of the Assessment of soil contamination and Remediation needs 214/3007 (2007).

21 Muller G, Index of geoaccumulation in sediments of the Rhine river. GeoJournal 2:108-118 (1969).

22 Hakanson L, An ecological risk index for aquatic pollution control. A sedimentological approach. Water Res 14:975-1001 (1980).

23 Buat-Menard P and Chesselet R, Variable influence of atmospheric flux on the trace metal chemistry of oceanic suspended matter. Earth Planet Sci Lett 42:399-411 (1979).

24 Cheng JL, Shi Z and Zhu YW, Assessment and mapping of environmental quality in agricultural soils of Zhejiang Province, China. J Environ Sci 19:50-54 (2007).

25 Tomlinson DL, Wilson JG, Harris CR and Jeffrey DW, Problems in the assessment of heavy metal levels in estuaries and the formation of a pollution index. Helgolander Meeresuntersuchungen 33:566-575 (1980).

26 Thabet AM, Mohamed AKM, Ragab R and Mahmoud AG, Application of pollution indices for evaluation of heavy metals in soil close to phosphate fertilizer plant, Assiut, Egypt. Assiut Univ Bull Environ Res 17:45-55 (2014).

27 Qingjiea G, Deng J, Xiang Y, Wang Q and Yang L, Calculating pollution indices by heavy metals ecological geochemistry assessment and 
a case study in parks of Beijiing. J China Univ Geosci 19:230-241 (2008).

28 Hong-gui $D$, Teng-feng G, Ming-hui L and Xu D, Comparative assessment model on heavy metal pollution in soil. Int J Electrochem Sci 7:5286-5296 (2012).

29 Ntzala G, Investigation of soil pollution level with treated municipal wastewater and sludge and their effect on soil and plants of lettuce (Lactuca sativa var Longifolia). M.Sc. thesis, University of loannina Department of Environmental and Natural sources, Management, Agrinio, Greece (in Greek) (2011).

30 Gallardo-Lara F and Nogales R, Effect of the application town refuse compost on the soil plant system: a review. Biol Wastes 19:35-62 (1987).

31 Hattab N, Soubrand M, Guégan R, Motelica-Heino M, Bourrat X, Faure $O$ et al., Effect of organic amendments on the mobility of trace elements in phytoremediated techno-soils: role of the humic substances. Environ Sci Pollut Res 21:10470-10480 (2014).

32 Kwiatkowska J, The effect of organic amendments on the phytoavailability of heavy metals in polluted soils. Ecohydrol Hydrobiol 6:181-186 (2006).

33 Xian X and Shokohifard Gl, Effect of pH and chemical forms and plant availability of cadmium, zinc and lead in polluted soils. Water Air Soil Pollut 45:265-273 (1989).

34 Papaioannou D, Comparative study of soil pollution indices via artificial enrichment of soil with heavy metal mixtures, under the effect of the treated municipal wastewater. PhD thesis, Hellenic Open University, School of Sciences and Technologies, Patras Greece (in Greek) (2017).

35 Brallier S, Harrison RB, Henry CL and Dongsen $X$, Liming effects on the availability of $\mathrm{Cd}, \mathrm{CU}, \mathrm{Ni}, \mathrm{Zn}$ in soil amended with sewage sludge sixteen years previously. Water Air Soil Pollut 86:195-296 (1996).

36 Alloway BJ, Thornton I, Smart GA, Sherlock JC and Quinn MJ, Metal availability. Sci Total Environ 75:41-69 (1988).

37 Kabala C, Chodak T, Szerszen L, Karczewska A, Szopka K and Fratczak $\mathrm{U}$, Factors influencing the concentration of heavy metals in soils of allotment gardens in the city of Wroclaw, Poland. Fresen Environ Bull 18:1118-1124 (2009).

38 Stevenson FJ and Cole MA, Cycles of Soil: Carbon, Nitrogen, Phosphorus, Sulfur, Micronutrients, 2nd edn. John Wiley and Sons Inc., New York (1999).

39 Lee DH, Zo YG and Kim SG, Nonradioactive method to study genetic profiles of natural bacterial communities by PCR-singlestrand-conformation polymorphism. Appl Environ Microbiol 62: 3112-3120 (1996).

40 Kandeler $\mathrm{E}$, Kampichler $\mathrm{C}$ and Horak $\mathrm{O}$, Influence of heavy metals on the functional diversity of soil microbial communities. Biol Fertil Soils 23:299-306 (1996).

41 Maha MESA, Efficiency of rice straw and its different composts in remediation of $\mathrm{Cd}$ and $\mathrm{Pb}$ contaminated sandy loam soil. Int J Plant Soil Sci 6:330-340 (2015).
42 Papaioannou D, Kalavrouziotis I, Koukoulakis P and Papadopoulos F, Critical ranges of pollution indices: a tool for predicting soil metal pollution under long term wastewater reuse. Toxicol Environ Chem 99:197-208 (2016).

43 Papaioannou D, Kalavrouziotis I, Koukoulakis P, Papadopoulos F and Psoma $\mathrm{P}$, Metal fixation under soil pollution and wastewater reuse. Desalin Water Treat 65:43-51 (2017a).

$44 \mathrm{Gad}$ N and Zaghloul AM, Characteristics of cobalt reactions in some alluvial soils as affected by rate and time of soil incubation. $J$ Appl Sci Res 2:226-246 (2006).

45 Lindsay WL, Chemical Equilibria in Soils. John Wiley and Sons, New York (1979).

46 McKenzie RM, The adsorption of lead and other heavy metals in oxides of manganese and iron. Aust J Soil Res 18:61-73 (1980).

47 Gustafsson JP, Pechova P and Berggren D, Modeling metal binding to soils, the role of natural organic matter. Environ Sci Technol 37:2767-2774 (2003).

48 Scheidegger AM and Sparks DL, Kinetics of the formation and the dissolution of nickel surface precipitates on pyrophyllite. Chem Geol 132:157-164 (1996)

49 Peltier E, Allada R, Navrotsky A and Sparks DL, Nickel solubility and precipitation in soils: a thermodynamic study. Clays Clay Miner 54:153-164 (2006).

50 Businelli D, Effect of carbonates and organic matter in retention and release of nickel by central Italy soil. Soil Sci 177:236-240 (2012).

51 Bolan NS, Naidu R, Syers JK and Tillman RW, Surface charges and solute interactions in soils. Adv Agron 67:87-140 (1999).

52 Richard FC and Bourg ACM, Aqueous geochemistry of chromium: a review. Water Res 25:807-816 (1991).

53 Kabata-Pendias A, Trace Elements in Soils and Plants, 4th edn. CRC press, Taylor \& Francis Group, Boca Raton London New York (2011).

54 Marschner $\mathrm{H}$, Mechanism of magnesium acquisition by roots from soils, in Manganese in Soils and Plants, ed. by Graham RD, Hannam RJ and Uren NC. Kluwer Academic Publishers, Dordrecht, The Netherlands, pp. 191-204 (1988).

55 Peak D and Sparks DL, Mechanism of selenate adsorption on iron oxides and hydroxides. Environ Sci Technol 36:1460-1466 (2002).

56 Frost RR and Griffin RA, Effect of pH on adsorption of Arsenic and Selenium from landfill leachate by clay minerals. Soil Sci Soc Am J 41:53-57 (1977).

57 Hyun S, Burns PE, Murarka I and Lee LS, Selenium (IV) and (VI) sorption by soils surrounding fly ash management facilities. Vadose Zone J 5:1110-1118 (2006).

58 Stumm W and Morgan JJ, Aquatic Chemistry: Chemical Equilibria and Rates in Natural Waters, 2nd edn. Wiley-Interscience Publication, pp. 145-389 (1981). 